кандидат педагогічних наук, доцент

(Житомирський державний університет імені Івана Франка) wlasolia@gmail.com

ORCID: $0000-0001-7258-2108$

\title{
ОСНОВНІ ПРІОРИТЕТИ РЕФОРМУВАННЯ ГРОМАДЯНСЬКОЇ ОСВІТИ В УКРАЇНІ
}

У статті розглядається проблема реформування громадянської освіти в Україні, визначено роль педагогічної науки й практики в контексті формування громадянських иінностей учнівської молоді. Наголошується на необхідності дослідження динаміки змін у процесі формування громадянської компетентності в період трансформачій суспільства. Автор розкриває категоріальний апарат дослідження та досліджує взаємозв'язок громадянської компетентності з іншими ключовими компетентностями, розглядає аспекти громадянського виховання в умовах гуманізації середньої освіти.

Ключові слова: громадянське виховання, громадянська освіта, громадянські иінності, активна громадянська позиџія, громадянська культура, інноваційний розвиток суспільства.

Постановка проблеми у загальному вигляді. Політичні, економічні та суспільні зміни в Україні ставлять під сумнів традиційний підхід до громадянського виховання школярів, який не може забезпечити достатню мотивацію до ініціативи та активності. Становлення громадянського суспільства в Україні, глобалізація, інтеграція України в світовий освітній простір посилюють потребу в науковому осмисленні досвіду громадянської освіти молоді в історичні ретроспективі та на сучасному етапі. Тому постає необхідність у формуванні нового типу громадянина, не тільки обізнаного в усіх політичних, економічних та суспільних змінах, але й активної особистості, здатної набувати необхідних навичок громадянської активності та соціальної взаємодії, брати участь у вирішенні суспільно значимих завдань своєї громади та країни.

Детермінуючими умовами для формування громадянських цінностей учнів освітніх закладів виступає нині низка державних нормативно-правових документів різного рівня, в яких визначено стратегічний курс держави на гуманізацію освіти, соціалізацію учнів, їх самоідентифікацію, громадянське становлення, створення в освітніх організаціях умов для розвитку особистості, що володіє високим рівнем громадянської культури, здатністю самостійно приймати конструктивні рішення в ситуаціях вибору, готовністю до активної участі в житті громадянського суспільства й держави, зокрема "Концепція національної системи виховання", "Концепція національно-патріотичного виховання", "Концепція Загальнодержавної цільової програми патріотичного виховання громадян на 2013-2017рр. ", "Концепція громадянської освіти та виховання в Україні", "Державна національна програма "Освіта" (Україна XXI століття)", "Національна стратегія розвитку освіти в Україні на період до 2021 року", Закони України "Про освіту", "Про додаткові заходи щодо підвищення якості освіти в Україні", "Про невідкладні заходи щодо забезпечення функціонування та розвитку освіти в Україні", в яких регламентуються педагогічні акценти підготовки сучасного школяра освітнього закладу, закладено основи для побудови педагогічної системи формування громадянської культури як інтегральної характеристики випускників, що створить можливості для успішної самореалізації людини.

Зв'язок із важливими науковими i практичними завданнями. Проблема громадянського виховання сучасного школяра, формування громадянського ідеалу в новій українській школі, роль учителя-предметника у процесі урочної та позаурочної діяльності, взаємозв'язок сім'ї та освітнього закладу, принципи народності, гуманізму, культуровідповідності у навчально-виховному процесі висвітлені в працях Г. Ващенка, О. Духновича, А. Макаренка, С. Русової, М. Стельмаховича, В. Сухомлинського, К. Ушинського. Проблему формування у свідомості учнів орієнтації на громадянські цінності розкрили у своїх дослідженнях Р. Свтушенко, П. Кендзьор, О. Кузьменко, О. Пометун, А. Сбруєва, О. Сухомлинська, К. Чорна та ін., формування громадянської компетентності висвітлювали В. Андрущенко, І. Бех, М. Боришевський, П. Вербицька, І. Зязюн, В. Кремень, В. Кузь, Г. Пустовіт, М. Чєпіль та ін., формування у молоді громадянської активності та соціальної взаємодії дослідили Г. Васьківська, В. Горбатенко, Н. Лавриченко, В. Москаленко, В. Оржеховська та ін.

Виклад основного матеріалу з обгрунтуванням отриманих наукових результатів. Об'єктивна потреба у модернізації навчально-виховного процесу освітнього закладу, спрямованого на вирішення проблеми громадянського виховання молоді, актуалізує вивчення пріоритетних тенденцій реформування громадянської освіти в Україні. 3 моменту набуття Україною незалежності прагнення вирішити проблему формування системи громадянських цінностей, громадянської компетентності, культури та активності особистості змінило суспільні процеси, вплинуло на провідні завдання розбудови громадянського суспільства та правової держави, обумовило роль освітніх закладів та вчителя у процесі формування громадянина України. 
Аналізуючи праці науковців-дослідників 3 проблеми громадянської освіти зазначимо, що як педагогічне явище громадянська освіта з'явилася в Україні на початку XXI століття. У державних документах визначено мету виховання - формування патріотичних цінностей, переконань, поваги до культурного та історичного минулого України, виховання поваги до Конституції України, Законів України, державної символіки, формування готовності до участі в процесах державотворення, уміння визначати форми та способи своєї участі в життєдіяльності громадянського суспільства, готовності взяти на себе відповідальність, здатності розв'язувати конфлікти відповідно до демократичних принципів, формування толерантного ставлення до інших народів, культур й традицій тощо [1;2;3].

У Концепції громадянської освіти та виховання з'ясовано необхідність формування сприятливого середовища для становлення в Україні громадянського суспільства, досягнення європейських стандартів забезпечення та захисту прав й свобод людини та громадянина, синтез міжнародних стандартів та національну специфіку, традицій, досліджень українських науковців, розробка й реалізація на цій основі моделі громадянської освіти у шкільну практику.

Одним із завдань сучасної освіти $є$ розробка категоріального апарату громадянської освіти на державному рівні. Становлення громадянського суспільства розглядається вченими як середовище, в якому формується громадська думка. За відсутності такого середовища, відсутня й можливість для особистості стати активною, толерантною, доброчесною, із сформованою громадянською культурою.

У новому Законі про освіту серед ключових компетентностей, що відповідають меті та принципам освіти, громадянська компетентність визначається як така, що пов'язана 3 ідеями демократії, справедливості та рівності, добробуту та здорового способу життя. Результати аналізу державних документів та наукових праць дослідників свідчать про відсутність єдиного трактування поняття "громадянська освіта" та "громадянське виховання", в першу чергу, через складність їх складність та багатоаспектність. Частина науковців, зокрема, І. Бех, В. Вербицький, П. Вербицька, М. Свтух та ін., громадянську освіту розуміють як процес формування системи громадянських цінностей у дітей та молоді, а також розвиток інтелектуальних, моральних та творчих якостей особистості; інші - як процес виховання громадян суспільства і країни (Желіба О., О. Пометун та ін.).

Громадянська компетентність у навчально-пізнавальної діяльності передбачає самостійний пошук та отримання інформації з різних джерел, уміння іï аналізувати та критично осмислювати; у суспільнополітичній та правовій діяльності - реалізацію прав та обов'язків громадянина, виконання функцій громадянина у взаємодії з іншими людьми та владою). Громадянська компетентність визначається нами як цілісне інтегроване утворення, що забезпечує орієнтацію у сучасному суспільно-політичному житті країни, участі в діяльності органів місцевого самоврядування, захист власних інтересів, прав і свобод, задоволення інтересів та захисту права людини і громадянина тощо [4]. Громадянська компетентність розкривається через ключові компетентності, зокрема загальнокультурну компетентність - аналіз, оцінка досягнень національної науки і культури, орієнтація в культурному та духовному просторі сучасного українського суспільства, єдність індивідуальних, громадянських та загальнолюдських цінностей, толерантна поведінка; дослідницьку компетентність - аналіз та оцінка сучасної соціальної ситуації; соціальну компетентність - вибір та прийняти рішення в конкретній соціальній ситуації, пошук вирішення соціальної проблеми; комунікативну компетентність - взаємодія з іншими людьми в процесі розв'язання певної соціальної проблеми тощо. Громадянська освіта тісно пов'язана 3 формуванням соціально-політичної компетентності особистості у суспільній сфері, яка передбачає, перш за все, політичну, правову й економічну освіченість й здатність керуватися відповідними знаннями в умовах перебудови суспільства.

Громадянське виховання передбачає формування громадянськості як інтегрованої якості особистості, що надає людині можливість відчувати себе морально, соціально, політично, юридично дієздатною та захищеною. Соціальна відповідальність в усіх сферах суспільного життя $є$ одним із критеріїв громадянського суспільства, соціальна орієнтація передбачає задоволення суспільних потреб та інтересів членів суспільства.

Громадянська освіта виступає засобом подолання політичної апатії, анемії, навчання мирних способів політичної поведінки, прийомів розв'язання соціальних проблем й конфліктів, впливу на владу [6: 35].

На нашу думку, громадянське виховання можна розглядати як ціннісну орієнтацію індивіда, яка проявляється у формуванні духовно-моральних та особистісних якостей, громадянських цінностей, поглядів та переконань, свідомої активної діяльності молодої людини на користь суспільства та своєї країни, яка передбачає уміння та навички критичного мислення для неупередженої оцінки, толерантного ставлення та орієнтації на демократичні принципи та пріоритети. Громадянське виховання неперервний цілеспрямований процес, який охоплює усі сфери життєдіяльності людини (особисту, сімейну, професійну, суспільну) та передбачає інтеграцію в зміст освіти навчального закладу, а не обмежується окремими курсами чи формами діяльності $[7 ; 8]$.

Сутність громадянської освіти полягає у формуванні знань, умінь та навичок - знань про ідеали, цінності (свобода, справедливість, толерантність, міжкультурне взаєморозуміння, захист довкілля та ін.), 
права та свободи, культуру, суспільство, умінь та навичок участі у громадському житті суспільства, умінь вирішувати конфлікти, вступати в комунікацію й співпрацювати, в тому числі й з представниками влади, умінь свідомо й відповідально обирати, критично мислити, - необхідних для існування особистості у сучасному суспільстві, які визначають громадянську компетентність молодої людини, політичну, соціальну та економічну освіченість.

Отже, громадянськість - це сукупність якостей особистості, яка передбачає сформовану свідомість, почуття патріотизму, причетності до історичної долі вітчизни та свого народу, усвідомлення себе повноправним членом соціальної спільноти. Громадянськість, громадянська позиція людини пов'язані 3 почуттям гордості за свою країну, іiі традиції, звичаї, символи (герб, гімн, прапор), з повагою до прав та обов'язків громадянина, до Конституції держави.

Сензитивним періодом для громадянського самовизначення особистості є старший шкільний вік, період формування взаємин "Я і суспільство", бачення свого місця у суспільстві, що стає можливим за умови формування системи громадянських цінностей, мотивів та потреб. Громадянське самовизначення особистості розглядається як соціально значущий вибір, здійснений випускником освітнього закладу на основі сформованої системи громадянських цінностей, ідентифікації Я 3 ідеалами суспільства, усвідомлення себе і своєї ролі у світі та виступає важливим фактором психічного розвитку особистості і особливим новоутворенням юнацького віку (Л. Божович, Л. Виготський).

Процес формування активної громадянської позиції учнів старшої школи є залежним від багатьох взаємообумовлених факторів, зокрема безперервності громадянської освіти, розробці регіональної системи громадянської освіти, рівня громадянської активності школярів, реалізації демократичних принципів становлення системи громадянської освіти (плюралізму, об'єктивності, демократизму, толерантності, орієнтації на цінності та ідеали гуманізму) та чіткого бачення результату громадянського виховання - сформованості громадянських якостей соціально активної, компетентної молодої людини на основі знань, умінь та навичок, що сприяють соціалізації старшокласника у динамічному суспільстві [9]. В цьому контексті знання передбачають розуміння державних процесів та напрямків державної політики, усвідомлення результатів історичних та політичних подій в країні, уміння взаємодіяти, контролювати, впливати та критично оцінювати інформацію або ситуацію, відстоювати власну думку, публічно чи приватно обговорювати проблеми, слухати й розуміти інших, взаємодіяти з різними верствами суспільства, структурними одиницями влади, представниками різних культур - дадуть можливість особистості брати участь в управлінні державою, переносити знання 3 освітнього середовища навчального закладу у життя суспільства.

Громадянська активність передбачає свідому готовність молодої людини до участі у суспільнокорисній діяльності, умінь бути відповідальним за наслідками своїх дій, підтримці принципу більшості, але визнання права меншості, підпорядкування особистих бажань та інтересів суспільному благу тощо.

Важливу роль у формуванні громадянської компетентності відіграють зміст освіти, організація навчально-виховного процесу, створення освітнього середовища, спосіб взаємодії суб'єктів навчальновиховного процесу, розробка нових підручників, поєднання різних форм навчання та виховання, відповідність змісту програм освіти реальним інтересам та потребам різних соціальних верств населення. У зв'язку з цим постає питання про роль навчальних предметів у процесі формування громадянської компетентності, зокрема предметів гуманітарного циклу, тому активна громадянська позиція старшокласників є продуктом урочної та позаурочної діяльності і залежить як від застосування інноваційних педагогічних технологій, так від включення особистості старшокласника у соціальне середовище. Крім цього, при формуванні змісту освіти необхідно розглядати навчальний процес як історичну категорію, своєрідну модель суспільства щодо підготовки молоді до життя та діяльності в даному суспільстві. Тому важливим є освітній простір, який забезпечує єдність в розумінні цінностей людини, громадянина та патріота, завдань освітніх закладів та соціокультурного середовища.

Висновки та перспективи подальшого дослідження проблеми. Основними пріоритетами реформування освіти на сучасному етапі $\epsilon$ розробка і створення державної та громадської, соціально орієнтованої, безперервної системи виховання i навчання учнів освітніх закладів, особливо старшокласників, забезпечення умов для формування системи громадянських цінностей школярів, становлення їх громадянськості як основи національного патріотизму та засобу виховання законослухняного громадянина держави, формування громадянської компетентності учнів старшої школи, а також реалізація громадянської політики в інтересах соціалізації особистості та розвитку правової держави загалом.

\section{СПИСОК ВИКОРИСТАНИХ ДЖЕРЕЛ ТА ЛІТЕРАТУРИ}

1. Проект Концепції Загальнодержавної цільової соціальної програми патріотичного виховання населення на 2013 - 2017 роки [Електронний ресурс]. - Режим доступу: http:/hainyzhnyk.in.ua/doc2/2011\%2812\%29.proekt.php.

2. Концепція середньої загальноосвітньої школи України [Електронний ресурс]. - Режим доступу: http://naps.gov.ua/ ua/activities/nsko/. - 26 c. 
3. Концепція "Нова школа. Простір освітніх можливостей" [Електронний ресурс]. - Режим доступу: http://mon.gov.ua/ activity/education/zagalna-serednya/ua-sch-2016/. - 40 c.

4. Шестопалюк О. Громадянська освіта як фактор формування громадянських компетентностей сучасної молоді / О. Шестопалюк // Рідна школа. - № 3 (березень). - 2010. - С. 33-35

5. Громадянська освіта : теорія і методика навчання : [посібник для студентів вищих навчальних закладів]/ Т. Асламова [та ін.]. - К. : Етна-1, 2008 - 174 с.

6. Кизенко В. Громадянська освіта і виховання - основа громадянського суспільства // Біологія і хімія в рідній школі. - 2015. - № 1. - С. 34-37

7. Горпинюк В. Соціально-професійне самовизначення молоді як рушійної сили середнього класу в громадянському суспільстві // Освіта і управління. - 2011. - Т. 14. - № 2-3. - С. 7-15.

8. Клепко С. Громадянська освіта: утопії, моделі, філософії / С. Клепко // Наук. і освітня методології та практики. - К. : ЦГО НАН України. - 2003. - С. 409-424.

9. Пометун О. Теоретичні засади формування громадянської компетентності учнівської молоді / О. Пометун // Управління школою. - 2005. - № 8 (92). - Березень. - С. 5-8.

\section{REFERENCES (TRANSLATED \& TRANSLITERATED)}

1. Proekt Kontseptsii Zahal'noderzhavnoi tsil'ovoi sotsial'noi prohramy patriotychnoho vykhovannia naselennia na 2013 - 2017 roky [Draft Concept of the National Target Social Program for Patriotic Education of the Population for 2013-2017] [Elektronnyi resurs]. - Rezhym dostupu : http://hai-nyzhnyk.in.ua/doc2/2011\%2812\%29.proekt.php.

2. Kontseptsiia seredn'oi zahal'noosvitnioi shkoly Ukrainy [Concept of the Secondary Comprehensive School of Ukraine] [Elektronnyi resurs]. - Rezhym dostupu : http://naps.gov.ua/ ua/activities/nsko/. - $26 \mathrm{~s}$.

3. Kontseptsiya "Nova shkola. Prostir osvitnikh mozhlyvostei" [Concept of New School. Educational Opportunity Space] [Elektronnyi resurs]. - Rezhym dostupu : http://mon.gov.ua/ activity/education/zagalna-serednya/ua-sch2016/. $-40 \mathrm{~s}$

4. Shestopaliuk O. Hromadyans'ka osvita yak faktor formuvannia hromadyans'kykh kompetentnostei suchasnoi molodi [Civic Education as a Factor in the Formation of Civic Competences of Modern Youth] // Ridna shkola [Native School]. - №3 (berezen'). - 2010. - S. 33-35.

5. Hromadyans'ka osvita : teoriya i metodyka navchannia [Civic Education: Theory and Methods of Teaching] : [posibnyk dlia stud. vyshch. navch. zakladiv]. - K., 2008. - $174 \mathrm{~s}$.

6. Kyzenko V. Hromadyans'ka osvita i vykhovannia - osnova hromadyans'koho suspil'stva [Civic Education and Education are the Foundation of Civil Society] // Biolohiya i khimiia v ridnii shkoli [Biology and Chemistry in Native School]. - 2015. - № 1-S. 34-37.

7. Horpyniuk V. Sotsial'no-profesiine samovyznachennia molodi yak rushiinoi syly seredn'oho klasu v hromadyans'komu suspil'stvi [Socio-Professional Self-Determination of Youth as a Driving Force of the Middle Class in Civil Society] // Osvita i upravlinnia [Education and Management]. - 2011. - T. 14. - № 2-3. - S. 7-15.

8. Klepko S. Hromadyans'ka osvita: utopii, modeli, filosofii [Civic Education: Utopia, Model, Philosophy] / S. Klepko // Nauk. i osvitnian. metodolohiyi ta praktyky. - K. : TS·HONAN Ukrainy. - 2003. - S. 409-424.

9. Pometun O. Teoretychni zasady formuvannia hromadyans'koi kompetentnosti uchnivs'koyi molodi [Theoretical Principles of Students' Civic Competence Formation] // Upravlinnia shkoloiu [School Management]. - 2005. № 8 (92). - Berezen'. - S. 5-8.

\section{Власенко О. Н. Основные приоритеты реформирования граэданского образования в Украине.}

В статье рассматривается проблема реформирования гражданского образования в Украине, определена роль педагогической науки и практики в контексте формирования гражданских иенностей школьников. В статье подчеркивается необходимость исследования динамики изменений в процессе формирования гражданской компетентности в период трансформаџии общества. Автор раскрывает категориальный аппарат исследования, исследует взаимосвязь гражданской компетентности с другими ключевыми компетенциями, рассматривает аспекты гражданского воспитания в условиях гуманизаџии среднего образования.

Ключевые слова: гражданское воспитание, гражданское образование, гражданские ченности, активная гражданская позиция, гражданская культура, инновационное развитие общества.

\section{Vlasenko O. M. The Main Priorities of Citizenship Education Reforms in Ukraine.}

The article examines the problem of reforming citizenship education in Ukraine, defines the role of pedagogical science and practice in the context of the formation of youths' civic values. The article emphasizes on the necessity of studying the dynamics of changes in the process of citizenship competence formation in the period of society transformation. The role of the pedagogical theory and practice in the civil values formation of the Ukrainian youth was determined. It was emphasized on the creative citizenship activity of the high school students as a subject of citizenship education and a factor for the civic values formation. The author reveals the categorical apparatus of the study and investigates the relationship of citizenship competence with other key competencies, examines the aspects of citizenship education in the conditions of humanization of secondary 
education. The main strategic priorities are: the basic value orientation of educational development, modernization of educational content, the implementation of an adequate structure of Ukrainian school, reliance on innovative learning, the application of new methods and technologies of teaching and assessing learning outcomes, competence approach, improvement of teacher training, capable of becoming agents of change.

Key words: citizenship education, civic values, active citizenship, citizenship culture, innovative development of society. 